\title{
Le Jardin
}

Tant que les fleurs

Ne se meurent

Rien ne changera

Tant que l'herbe

Ne se gerbe

Tout restera.

Mais ces fleurs sont mortes

Et celles-ci sont nées

Et cette herbe n'est plus

Que celle-là renouvelée

Tout change et tout s'échange

Une fleur contre une autre

L'herbe qui se réverdit

Renaît encore tout autre.

\section{Villanelle}

Chaque chose

S'oppose

Chaque être

Est lettre

La rose

S'arrose

Ses larmes

La charment

La pluie

S'enfuit

Ses gouttes

S'égouttent

La mer

S'affaire

Ses vagues

Divaguent
La lune

S'allume

Son clair

S'éclaire

Le jour

S'ajoure

La nuit

Se nuit

La guerre

S'avère

S'éclate

Se flatte

La paix

Une plaie

Au flanc

Du camp
Les mots

Sont faux

Les rimes

s'abîment

Le gouffre

Se rouvre

Chaque chose

S'oppose.
Kay Redhead

(York University) 